\title{
A Public Option in Banking
}

\author{
Postal Banking
}

Mehrsa Baradaran

There are many services and utilities that would benefit from a public option because markets are either monopolized or failing. Whatever the merits of the public option in other fields, the banking system is undemocratic without a public option. This is because most basic banking services - deposit-taking, financial transactions, lending - operate using a federal government platform, network, or guarantee. Federal government support is not a mere subsidy because the federal infrastructure does not simply enhance bank profits, but it makes the entire modern banking enterprise possible. In other words, this framework not only enhances, but enables modern banking markets. Most of this support, like FDIC insurance, is invisible to the average consumer and usually unnecessary, while some of this support is implicit and rare like the bank bailouts. All of it is meant to induce public trust and participation in the banking sector. Scholars have called banks "a franchise" and courts have called them "instrumentalities" of the federal government. ${ }^{1}$ Banks are granted a charter to operate by the federal government, which allows them to "plug in" to the government payments and credit structure. Thus, the hidden monopoly power in the banking sector is the federal government, making it essential to provide access to all.

Insofar as banks operate in tandem with government credit and payments facilities, it stands to reason that they must make their services available to all. Yet they are not currently under any such mandate of accessibility. This is due both to the fact that banks have become more enmeshed with the federal infrastructure over time, especially after the Progressive Era and the operational legislation and institutional framework inaugurated by the New Deal. More recently, an erosion of legal requirements on banks has enabled banks to abandon lower-profit regions and customers under the guise of "inefficiency" and market competition. ${ }^{2}$ Thus, the

1 See Starr Int'l Co. v. Fed. Reserve Bank of N.Y., 742 F.3d 37, 40 (2d Cir. 2014) (FRBs are instrumentalities of the federal government and the operating arms of its central bank); Robert C. Hockett \& Saule T. Omarova, The Finance Franchise, 102 Cornell L. Rev. 1143, 1147 (2017).

2 Mehrsa Baradaran, Banking and the Social Contract, 89 Notre Dame L. Rev. 1283, 1285-86 (2014); For a modern example, see Jeanna Smialek et al., Banks Want Efficiency. Critics Warn of Backsliding., N. 
United States has a federally sponsored banking system that is exclusionary. Those who are excluded are the most financially vulnerable individuals and communities who are forced to pay the most for services. Thus, a public option in banking is essential to making the system democratic.

This chapter will make the case for postal banking as a public option available to all Americans. Ganesh Sitaraman and Anne Alstott define a public option as a service provided by the government that is available to all, competes in a free market, and charges all people the same amount for the same services. ${ }^{3}$ This chapter proposes a public option in banking using the post office as the point of delivery. Postal banking could include a range of financial services, but imperative to full financial inclusion would be to provide access to the payments system or in other words, simple checking services. Postal banking could also offer a public option in small credit. Payday lending is a large and fairly new industry that provides high-cost small loans to the most vulnerable Americans. The industry has evaded state and federal regulation thus far, both due to high demand for loans, successful lobbying efforts by the industry, and the failure of the Trump administration's Consumer Financial Protection Bureau (CFPB) in enforcing payday regulations adopted by the Obama administration. Offering a public option for credit reduces the need to regulate usury and push for the elimination of payday lenders. Instead of forcing private lenders to adopt a low interest rate or alternatively allowing the status quo wherein low-income borrowers have no option but to borrow money at crushingly high interest rates. A public option in lending could alleviate some of those harsh penalties for many low-income Americans who must rely on these loans. Lending has many risks as well as rewards, and this chapter will also discuss some of the drawbacks of a public option and suggest how some of those obstacles can be averted.

Crucially, postal banking is not a new idea nor is it a radical departure from history. The United States had a successful postal banking system from 1910 until 1966 as do many other countries worldwide. The post office has had a historic connection with banking services as both are essentially public goods and necessary for participation in commerce. Postal banking in America was among a slate of Progressive Era policies adapted to create more egalitarian markets. At a crucial turning point in American banking policy, policymakers tackled inequality and banking instability. This was in the early 1900s, but in many ways, economic conditions are similar today. What the progressive reformers understood and what modern politics has forgotten is that credit policy is public policy. To the extent that certain communities are excluded from mainstream banking institutions, their exclusion is a problem of public policy and not a gap in the market.

Y. Times (August 20, 2019), www.nytimes.com/2019/08/20/business/bank-regulation-federalreserve.html.

3 Ganesh Sitaraman \& Anne L. Alstott, The Public Option: How to Expand Freedom, Increase Opportunity, and Promote Equality (2019). 


\subsection{BANKING AS A PUBLIC UTILITY}

When confronting the power of banking trusts and monopoly power over credit, Justice Louis Brandeis proposed that certain industries were especially suited for a public utility nature. Banking or railroads, for example, were considered service essential to full participation in commerce. In these cases, Brandeis offered an alternative to create a public utility. Such a utility could either compete with the market or offer an alternative. Brandeis believed banking to be among the industries that might be considered a public utility because, as he explained "deposit banking should be recognized as one of the businesses "affected with a public interest'." 4 This was because banks gained their market power and their profits through the use of “other people's money." President Roosevelt did not make banks a public utility, but his administration did embed public duties in all the legislation governing banks during the New Deal. ${ }^{5}$ Many of those laws have been eroded since even as banks are ever more reliant on public services for their operations.

Today, each aspect of banking, including deposits, loans, and simple financial transactions, relies on a robust network of government support. ${ }^{6}$ Each time a bank sends or accepts money, they are using the Federal Reserve's payments system. ${ }^{7}$ Banks can take and lend customer deposits and engage in fractional reserve lending (and the magic money multiplier effect this enables) only because customer deposits are insured by the FDIC. Unlike all other corporations, banks pay virtually nothing for their funding (customer deposits) because of this federal government subsidy. ${ }^{8}$ And when the FDIC fund goes into the red - as it did in 2008 - these deposits are backstopped by the full faith and credit of the US Treasury. ${ }^{9}$ On the asset side, most mortgages and student loans are guaranteed, bundled, or subsidized by the FHA or

4 Louis D. Brandeis, Other People's Money 64 (1914).

5 For a more robust discussion, see Mehrsa Baradaran, How the Other Half Banks: Exclusion, Exploitation, and the Threat to Democracy 211 (2015); Baradaran, supra note 2, at 1297-98.

6 See Justin Pritchard, Understanding the FDIC, The BALANCE (April 29, 2020), www.thebalance.com /what-is-the-fdic-315786 [https://perma.cc/B2TZ-CDA9].

7 Carol Coye Benson et al., Payments Systems in the U.S.: A Guide for the Payments Professional XX (3rd ed. 2017).

8 Banks do pay into the FDIC insurance fund through premiums, but most scholars agree that the premiums are underpriced. Furthermore, it is not just the actual funds that are paid out in the event of a failure that is of importance here. It is the fact that bank deposits are backed by the full faith and credit of the federal government making them a safe repository for their customers' funds. "Until the early 1990s, the FDIC levied flat-rate insurance premiums on banks as a function of deposits, but not the banks' risk. In 1991 the FDICIA required that the FDIC introduce risk-based premiums. However, to date, the range of premiums is much narrower than the range of risk exposures of the FDIC to individual bank failures. Under the Deposit Insurance Funding Act of 1996, when the FDIC reserve fund exceeds 1.25 percent of deposits, the 'safest' of banks pay no deposit insurance premium meaning that recently more than 90 percent of banks holding over 90 percent of total bank assets paid NO premiums." Joe Peek \& James A. Wilcox, The Fall and Rise of Banking Safety Net Subsidies, in ToO Big to Fail: Policies and Practices in Government Bailouts 177-78 (Benton E. Gup ed., 2004).

9 Id. 
the Government Sponsored Entities (GSE's) Fannie Mae, Freddie Mac, Ginnie Mae, and Sallie Mae. ${ }^{10}$ These entities purchase almost every mortgage and student loan in the country and resell them to investors. And when these institutions fail, they too have the implicit backing of the federal government. ${ }^{11}$ These GSEs enable banks to lend exponentially more loans than what their customer deposits would allow. ${ }^{12}$ At the crux of our banking system, then, is a state-enabled credit system.

Deposits and loans - assets and liabilities - are all supported by the federal government. And that's just the tip of the iceberg. When an individual has a liquidity crisis or can't pay a bill, she or he has to go to a payday lender and take out an emergency small loan at around 400 percent APR. ${ }^{13}$ In contrast, when a bank has a liquidity crisis, they are able to go to the Fed's discount window, which provides banks loans at 0.5 percent higher than the Federal Funds rate, which is currently set at 2.0 percent ${ }^{14}$ None of this takes into account the government bailout, the staggering magnitude of which went on full display after the 2008 financial crisis. ${ }^{15}$ Using its $\$ 13(3)$ emergency lending powers, the federal government bailed out a failing banking industry with over a trillion dollars of equity infusions, loans, guarantees, asset purchases, and other forms of financial support. ${ }^{16}$ The help came on very favorable terms with interest rates not available on the market. The

10 Sallie Mae ceased being a GSE, and became fully privatized, when Congress terminated its charter on December 29, 2004. At that point, the GSE became SLM Corporation, "a fully private sector corporation.” U.S. Dep't of Treasury, Lessons Learned from the Privatization of Sallie Mae 1 (2006), www.treasury.gov/about/organizational-structure/offices/Documents/ SallieMaePrivatizationReport.pdf [https://perma.cc/F5 4 -RSDE]. A table on page 3 of the above mentioned Treasury report distinguishes the former GSE-Sallie Mae from the fully privatized SLM corporation. Notable differences include: (1) the GSE's charter was created by an act of Congress; (2) the president appointed the GSE's board members; (3) the GSE could borrow up to \$1billion from the Treasury, whereas the SLM corporation cannot borrow from the Treasury; (4) the GSE's debt was eligible for federal open market purchases; (5) the GSE was exempt from SEC registration and financial and other filings with the SEC; and (6) the GSE was exempted from federal, state, and local income taxes. Id. at 3 .

${ }^{11}$ Fannie Mae and Freddie Mac were spun off of the federal government and privatized, which meant that they were run by a board of shareholders. It did not mean that they operated in normal markets. The market still treated them like government entities, meaning that they did not contemplate their failure. When they did fail because of the excessive risks their managers took, the government bailed them out without flinching. See id.

12 Id.

13 CFPB, What is a Payday Loan (June 2, 2017), www.consumerfinance.gov/ask-cfpb/what-is-a-paydayloan-en-1567/.

14 See Kimberly Amadeo, Federal Reserve Discount Window and How It Works, The Balance (November 26, 2018), www.thebalance.com/federal-reserve-discount-window-3305923 [https://perma .cc/L97W-4Z2B]; Bd. Of Governors of the Fed. Res. Sys., Monetary Policy, www .federalreserve.gov/monetarypolicy/openmarket.htm [https://perma.cc/ST 3 K-3TRM].

15 See Peek \& Wilcox, supra note 8, at XX.

16 The actual amount of the bailout is difficult to determine because much of it was in guarantees. The special inspector general for TARP estimated a total potential support package of $\$ 23.7$ trillion, or over 150 percent of the U.S. GDP. However, many of these guarantees were never used. JOHNSON \& KWAK, 13 Bankers: The Wall Street Takeover and the Next Financial Meltdown 174 (2011). 
arrangement was so good that the CEO of one of the largest bailed out banks, upon seeing the terms of the deal, remarked, "This is very cheap credit!"

Then there are the unprecedented waves of asset purchases and money pumped through banks, ostensibly so that the money will pass through financial institutions and make it to the public. ${ }^{18}$ Three rounds of quantitative easing have left the Fed still holding over four trillion dollars in bank assets and the continuing interest on reserves that are still ongoing. Another less well-known example of monetary policy is Interest On Excess Reserves ("IOER"). In a payment that seems to violate what people may assume to be the laws of the market and basic common sense, the Federal Reserve pays billions of dollars in interest to banks on their reserves. ${ }^{19}$ In just one year, the Federal Reserve paid about $\$ 7$ billion in interest to commercial banks, including more than \$100 million to Goldman Sachs and more than \$90o million to JPMorgan Chase. The point of this payment is that it will "pass through" the banks to the depositor, but the IOER is in fact not being passed on but being absorbed by the bank as profits, and thereby increasing inequality. ${ }^{20}$ Because excess reserves pay higher interest than Treasury bills, there is no reason banks would pass up a risk-free, high-interest opportunity. Each dollar held on reserve is a dollar not lent for real estate, infrastructure, or business operations in the American economy. ${ }^{21}$

All this federal government support sets the banking sector apart from other business that must create its own wealth without the use of other people's money or cheap loans when they fall short. Banks and the government (and by extension the people) should have a mutually beneficial arrangement that consists of the government providing market-enabling structures and trust-inducing deposit insurance and banks, in return, playing their essential role in financing the expansion of the economy and serving the needs of their customers and local communities. The

17 David Wessel, in Fed We Trust: Ben Bernanke’s War on the Great Panic 240 (2009).

18 See Peek \& Wilcox, supra note 8, at 169-70.

19 Due to the massive amounts of money created by QE, bank reserves swelled to over \$1.7 trillion as of October 2018. This overage is called excess reserves and even though it was created by the federal reserve, banks earn interest on these reserves. These reserves comprise a substantial portion of the nation's monetary base. The Federal Reserve is using this payment, called an "administered rate" as its primary monetary policy tool post QE. Fed. Res. Bank of ST. Louis, Required Reserves of Depository Institutions (2018), https://fred.stlouisfed.org/series/REQRESNS [https://perma.cc /6BEF-MX4A]. Banks are required to hold roughly 10 percent of their deposits in reserves at the central bank. The required reserves on just customer deposits would equal roughly $\$ 189$ billion. See Walker F. Todd, The Problem of Excess Reserves, Then and Now, 8, 15 (Levy Econ. Inst., Working Paper No. 763, 2013).

20 This policy, which was meant to encourage lending by banks, has turned into a subsidy that in fact discourages lending because banks can earn more by "lending" customer deposits to the Federal Reserve than they can pursuing consumer or business loans. Excess funds can be rolled over at no cost and liquidated on the same day, making excess reserves more attractive than lending. Morgan Ricks, Money as Infrastructure, 2018 Colum. Bus. L. Rev. 757-62 (2018); Symposium, Darrell Duffie \& Arvind Krishnamurthy, Pass through Efficiency in the Fed's New Monetary Policy Setting 4 (August 25, 2016) (unpublished paper) (on file with the Federal Reserve Bank of Kansas City).

${ }_{21}$ Todd suggests that the Federal Reserve sell about $\$ 180$ billion in mortgage-backed securities or longer maturity Treasury securities per year in order to prevent future inflation. Todd, supra note 19, at 15-16. 
relationship can be described as a social contract or an implicit promise or exchange made by the government and the banks. ${ }^{22}$ Viewed from this lens, it becomes clear that this level of government support to the banking sector must mean that the government and by extension "the people" must be entitled to demand a banking sector that serves all of us.

\subsection{A PUBLIC OPTION IN BANKING}

The phrase "public option" entered the political lexicon during the health-care debates as an option among the other forms of health-care provisions. ${ }^{23}$ However, the concept of a public option has been around since the founding of the country. ${ }^{24}$ A public option is when the government enters a market and offers a product or service to compete with private companies. Government-funded health insurance would have been a public option. More common public options include public libraries, public pools, or the US Post Office. The government offers these services either through subsidies or at cost (as is the case with the post office). Private companies like bookstores or UPS can compete with the public option, but consumers can make a choice to use the public option. Broadly conceived, public options already exist in banking. The Federal Reserve's payments system is a public option. ${ }^{25}$ It competes with private payments providers, but banks can choose to use the Fed's payments system. Adam Levitin and Susan Wachter have also called the US housing finance system a public option and argue that federal government credit institutions and subsidies created the American mortgage. ${ }^{26}$ As Thomas Herndon and Mark Paul explain, "the creation of a stable mortgage structure during the New Deal provides an excellent case study of how public options can be used to regulate in the public interest by shielding households from risk." ${ }^{27}$

22 There is a long and rich philosophical discussion about the social contract between individuals and society. In general, social contract theory posits that individuals consent to surrender some natural liberty in exchange for protection or other benefit conferred by society. The relationship between the government and banks is similar. The social contract between individuals and the state has been taken up by Hobbes, Kant, Rousseau, Rawls, and others. Paul Tucker, Deputy Governor, Bank of England, Remarks at the British Bankers' Association Annual International Banking Conference, Regimes for Handling Bank Failures - Redrawing the Banking Social Contract (June 30, 2009), www.bis.org /review/rogo7o8d.pdf [https://perma.cc/NH6W-KHTU].

23 See Margot Sanger-Katz, The Difference Between a "Public Option" and "Medicare for All"? Let's Define Our Terms, N.Y. Times (February 19, 2019), www.nytimes.com/2019/o2/19/upshot/medicare-for -all-health-terms-sanders.html [https://perma.cc/6K8B-HG7M].

24 The Post Office was established during the Postal Act of 1792. Andrew Glass, Washington Signs the Postal Act: Feb. 20, 1792, PoliTico (February 20, 2008), www.politico.com/story/2008/o2/washingtonsigns-the-postal-act-feb-20-1792-008592.

25 See Bd. of Governors of the Fed. Reserve Sys., Payment System Risk, www.federalreserve.gov /paymentsystems/psr_about.htm [https://perma.cc/9K5 L-QQ 4 P ].

26 See Adam J. Levitin \& Susan M. Wachter, The Public Option in Housing Finance, 46 U.C. Davis L. Rev. 1111, 1119 (2013).

27 Thomas Herndon \& Mark Paul, A Public Banking Option 17 (2018), http://rooseveltinstitute.org/wpcontent/uploads/2018/o7/Public-Banking-Option-final.pdf [https://perma.cc/7HN3-EZJE]. 
The federal government also provides deposit insurance for banks. ${ }^{28}$ Banks pay premiums for the insurance, which makes deposit insurance resemble other public options, but FDIC insurance is not an "option." All banks must buy in to the scheme. Still, the innovation of a public and federal insurance scheme was crucial in stabilizing the banking sector and avoiding near-constant panics, runs, and crises. ${ }^{29}$ Despite many attempts at private deposit insurance, only federal insurance has been an effective antidote to runs. ${ }^{30}$

What I am proposing is a different sort of public option - a bank account and small credit option to compete with the check cashing and payday lending alternatives. In a way, a public option is the path not taken during the Progressive Era and in the New Deal reforms that followed it. The Progressive coalition, made up of Southerners and farmers, pushed for small community institutions instead of large federal ones. ${ }^{31}$ For instance, in their fight against monopolies, they preferred to break apart big companies and form smaller ones tied to each community. ${ }^{32}$ FDIC insurance itself was such a bargain. ${ }^{33}$

Reforming the banking sector could have taken a variety of forms: one was FDIC insurance that was first proposed by William Jennings Bryan, the Democrat who most embodied the progressive spirit at its height. FDIC insurance would stabilize banking by diminishing runs, but crucially, it would favor small local banks. The other option was the Republican option at the time, proposed by Teddy Roosevelt another icon of the Progressive era, but a Republican, who proposed postal banking as a potential reform after the Panic of 1907.34 Postal banking was not adopted in Teddy Roosevelt's administration, but he did set the ball rolling. Congress enacted the United States Postal Savings System (USPSS) in 1910 and President Taft signed the Act into law. ${ }^{35}$ Thus, offering postal banking is not a new enterprise, but a reconsideration of a path not taken during the New Deal.

Franklin Delano Roosevelt adopted many of the progressive reformers' agenda items and New Deal reformers viewed banking through the lens of a public utility. ${ }^{36}$

28 See Fed. Deposit Ins. Corp., Deposit Insurance FAQs, www.fdic.gov/deposit/deposits/faq.html [https://perma.cc/6VY4-U5ET].

29 See Richard Scott Carnell et al., The Law of Financial Institutions (5th ed. 2013); Richard S. Grossman, Unsettled Account: The Evolution of Banking in the Industrialized World since $1800246-50$ (2010).

30 See Roger Lowenstein, There's a Reason for Deposit Insurance, N.Y. Times (March 23, 2013), www .nytimes.com/2013/03/24/business/deposit-insurance-and-the-historical-reasons-for-it.html [https:// perma.cc/49K5-WLJ4].

${ }^{31}$ See Mehrsa Baradaran, Jim Crow Credit, 9 U.C. Irvine L. Rev. 887, 888, 900 (2019).

32 See id. at $887-88$.

33 See id. at 901.

34 See Theodore Roosevelt, President of the US, Seventh Annual Message (December 3, 1907) (transcript available in the University of Virginia Miller Center).

35 See Appendix B for the roll call vote results. 45 Cong. Rec. S2, 7766-68 (June 9, 1910).

36 See Jane W. D’Arista, The Evolution of U.S. Finance Volume II: Restructuring Institutions and MARKETS 204 (1994); Jeff Manza, Political Sociological Models of the U.S. New Deal, 26 Ann. Rev. of Soc. 297,298 (2000). 
Yet Roosevelt chose FDIC insurance instead of Treasury-backed deposit accounts (postal banking) to stabilize the banking sector. ${ }^{37}$ Postal banking remained viable and was even deployed by Roosevelt to help fund the war and alleviate the government debt from the Great Depression, but the public utility option - or the public option through postal banks - was left on the table as an abandoned progressive idea. ${ }^{8}$

Postal banking could have proved to be as effective as FDIC insurance in stabilizing the banking sector. Both were federal government supports of the banking sector - a federal backstop that could stop runs. FDIC insurance was a fund that would guarantee all deposits, but it was ultimately backed by the US Treasury. Postal banking was a public option - or a utility model of Treasury banking. ${ }^{39}$ Accounts held by the postal banks were directly backed by the US Treasury; therefore, the postal banks were immune to runs. They were immune not just because of the direct Treasury backstop, but because these banks did not engage in fractional reserve lending - the deposits were held as Treasury bonds or they circulated as excess liquidity in local banks. ${ }^{40}$ In either case, there was never a run on postal banks. ${ }^{41}$ In fact, recent economic research reveals that postal banking helped ease the general panic conditions during the Great Depression..$^{42}$ Panicked depositors fleeing from failing banks used postal banks as a safe alternative, which helped ameliorate the liquidity crisis in the banking sector. ${ }^{43}$

\subsection{MODERN POSTAL BANKING}

The basic idea of modern postal banking is a public bank that would offer a wide range of transaction services, including small lending. ${ }^{44}$ The post offices could offer these services at a much lower cost than banks and the fringe industry because they can use natural economies of scale and scope to lower the costs of the products. ${ }^{45}$ Their existing infrastructure significantly reduces overhead costs, and they do not have profit-demanding shareholders and thus would be able to offer products at cost. $^{46}$ As for communities without access to safe credit and banking services, the

37 See D'ARISTA, supra note 36 , at 65.

$3^{8}$ Id.

39 Id. at $65-68$.

$4^{\circ}$ Id.

$4^{1}$ Id.

42 See Mehrsa Baradaran, A Short History of Postal Banking, SLATE (August 18, 2014), https://slate.com /news-and-politics/2014/o8/postal-banking-already-worked-in-the-usa-and-it-will-work-again.html [https://perma.cc/F6M5-22CA].

43 See Steven Sprick Schuster et al., An Empirical History of the United States Postal Savings System 12-13 (Nat'l Bureau of Econ. Research, Working Paper No. 25812, 2019), https://ssrn.com labstract $=3306033$ [https://perma.cc/ZT2K-MZE 3$]$.

44 See Mehrsa Baradaran, It's Time for Postal Banking, 127 Harv. L. Rev. F. 165, 166 (2014).

45 Id.

$4^{6} \quad$ Id. at 167,172 . 
post office remains as one of the only public institutions that still serves these communities regardless of profits. The post office offers money orders, and many customers use money orders in lieu of a checking or savings account. ${ }^{47}$ Researchers Terri Friedline and Mathieu Despard concluded in their "Mapping Financial Opportunity" project that postal banking can best help rural areas that are banking deserts. ${ }^{48}$

Public options have recently begun to be studied in the legal and economic literature. ${ }^{49}$ Law Professors Morgan Ricks, John Crawford, and Lev Menand have suggested that the Federal Reserve should offer accounts directly to all individuals and businesses through a FedAccount, which they claim could be offered through the post office..$^{50}$ They argue that "restricting central bank accounts to an exclusive clientele (banks) is no longer justifiable on policy grounds if indeed it ever was." ${ }^{1}$ Their proposal for a public account at the Federal Reserve would extend to all businesses, individuals, and organizations. ${ }^{52}$ They state that based on the myriad public subsidies that banks receive from the Federal Reserve's monetary policy, providing a public option would put people in a similar position as the banks. ${ }^{53}$ After all, banks make billions per year just in interest payments on reserves (IOER) that they do not pass on to customers. ${ }^{54}$ Both postal banking and FedAccounts could be designed to create revenue for the post office and the Federal Reserve. ${ }^{55}$ Herndon

47 Id.

$4^{8}$ Terri Friedline \& Mathieu Despard, Mapping Financial Opportunity: Final Report 8-9 (2017), https://aedi.ssw.umich.edu/sites/default/files/publications/Mapping-Financial-Opportunity.pdf [https://perma.cc/V5AF-2FLF].

49 See, e.g., Ganesh Sitaraman \& Anne L. Alstott, The Public Option: How to Expand Freedom, Increase Opportunity, and Promote Equality (2019); Herndon \& Paul, supra note 27; Baradaran, supra note 44; Levitin \& Wachter, supra note 26; Morgan Ricks et al., FedAccounts, Vand. L. Res. PAPER 18-33 (December 2, 2018).

50 See Ricks et al., supra note 49 , at 1, 5 .

${ }^{51}$ Id. at 1 .

52 Id.

53 Special privileges for banks: In addition to US depository institutions, see 12 U.S.C. $\int 342$, the Federal Reserve is authorized to maintain accounts for the US Treasury, see 12 U.S.C. \& 391, certain government-sponsored enterprises in the residential mortgage area, see 12 U.S.C. $\iint 1435,1452$ (d) \& $1723 \mathrm{a}(\mathrm{g})$, foreign governments, banks, and central banks, see 12 U.S.C. $\iint 347(\mathrm{~d}) \& 358$, certain international organizations, such as the International Monetary Fund and the World Bank, see 22 U.S.C. $\$ 286(\mathrm{~d})$, and certain designated financial market utilities, see 12 U.S.C. $\$ 5465$, as well as assorted other governmental and government-sponsored entities that we omit here. We just say "banks" in the main text for expositional convenience.

54 See Morgan Ricks, Money as Infrastructure, 2018 Colum. Bus. L. Rev. 757, 794, 798 (2018).

55 For revenue projections for the post office, see U.S. Postal Serv., Office of Inspector Gen., Providing Non-Bank Financial Services for the Underserved 16 (2014). As for Fed Accounts, as Ricks, Crawford, and Menand explain, the FedAccounts would increase revenue. "Central banks' asset portfolio returns typically exceed their interest payments and other expenses by a wide margin. These earnings are called 'seigniorage': fiscal revenue from money creation. The amounts are large. The Fed remitted $\$ 98$ billion, $\$ 92$ billion, and \$9o billion in earnings to the US Treasury Department in 2015, 2016, and 2017, respectively. Because FedAccounts would probably greatly expand the Fed's balance sheet (see Part III.A), these remittances could easily double or triple, even after accounting for the costs of maintaining millions of retail accounts." Ricks et al., supra note 49, at 16-17. 
and Paul also propose a public banking option with two components: First, their public option would create a new public bank with basic deposit and transaction services and " "plain vanilla' consumer financial services, such as small-dollar loans, auto loans, and mortgages." Second, a public bank would "manage an online financial services marketplace, where public services would directly compete with private services." 56

One promising path toward effectuating a public option is to repurpose an old democratic institution: the post office. American banks long ago deserted most impoverished communities. But post offices, even two centuries later, have remained - still rooted in their original egalitarian mission. As America's oldest instrument of democracy in action, the Post Office can once again level the playing field and in the process. This is not a new or radical idea. The United States had a robust postal banking system from 1910 until 1966, and most other countries have offered or are still offering postal banking accounts. ${ }^{57}$ The idea has recently gained traction in the United States as well. I proposed postal banking in a 2012 article and have been actively involved in its promotion since. ${ }^{58}$ The Postal Service Inspector General issued a 2014 White Paper studying the issue. ${ }^{59}$ Senator Warren endorsed postal banking in 2015, and was followed by Senators Sanders and Gillibrand - both of whom have proposed legislation to this effect. ${ }^{60}$ The 2016 Democratic National Platform included postal banking. ${ }^{61}$ The postal workers unions also negotiated a postal banking pilot in their contract negotiations in $2015 .{ }^{62}$ As of this writing, the postmaster general has not supported postal banking and legislation has not been passed, but efforts to enact such reform are ongoing.

\section{$9 \cdot 4$ FINANCIAL INCLUSION}

The most important argument in favor of postal banking is that it has the potential to bank the unbanked and expand access to savings accounts that could diminish the need for fringe banking services. Postal banking can provide transactional services and small loans without life-crushing fees and interest. Critically, by making

56 HeRndon \& PaUl, supra note 27, at 20-21.

57 For more information, see Mehrsa Baradaran, How the Other Half Banks: Exclusion, Exploitation, and the Threat to Democracy (2015).

58 Mehrsa Baradaran, How the Poor Got Cut Out of Banking, 62 EmORY L. J. 483 (2013).

59 U.S. POSTAL SERV., supra note 55.

6o See Kevin Wack, Postal Banking is Back on the Table. Here's Why That Matters, Am. BANKER (April 26, 2018), www.americanbanker.com/opinion/postal-banking-is-back-on-the-table-heres-why-thatmatters [https://perma.cc/gZRX-9DBM] [note: I have worked on most of the senate and house legislation dealing with postal banking].

61 Democratic Platform Comm., 2016 Democratic Party Platform 11, https://democrats.org/wpcontent/uploads/2018/10/2016_DNC_Platform.pdf [https://perma.cc/9TYG-TDXW].

62 See Dave Johnson, Postal Workers and the Public Want a Postal Banking Public Option, HuffPost (February 19, 2015), www.huffpost.com/entry/postal-workers-and-the-pu_b_6717096 [https://perma.cc /E8DD-DTDW]. 
banking available to those deserted by a government-supported banking system, the state can minimize the threat to democracy posed by the heavily subsidized, exclusionary, and powerful banking sector.

Without bank accounts, many Americans do not save - or they store their savings at home under the proverbial mattress. ${ }^{6} 3$ More than 40 percent of Americans do not have even $\$ 500$ in savings and would need to borrow if they had a shortfall - over 60 percent would need to borrow $\$ 1000$ if they faced a financial emergency. ${ }^{64}$ Many Americans do not save because they do not earn enough even while working full time, but even if they have money to save; most accounts are not accessible to those with small savings. ${ }^{65}$ Cash savings are vulnerable to theft and loss. ${ }^{66}$ Research abroad has demonstrated that increased access to a savings account enhances economic welfare and other important outcomes. ${ }^{67}$ Having a safe, low-cost, and easy savings account could lead to more savings, which could diminish the need for payday loans when families hit a snag. ${ }^{68}$ When individuals can dip into savings, they are less likely to need payday loans. A postal savings account made possible through a local postal branch could significantly ease the burden on many families leading to more savings. There is some evidence for this historically. When the postal savings accounts were first established in 1910, they became very popular with immigrants living in urban areas who had previously stored their earnings in "stocking banks." ${ }_{9}$ Most of the deposits into the early savings banks came from the home hiding places of these immigrants. ${ }^{70}$ Historian Sheldon Garon has contrasted the low savings rates in the United States versus higher rates in Germany and Japan and has surmised that the difference had much to do with the strong network of postal banks that remained

63 Pew Charitable Trs., Drowning in Debt: A Health Impact Assessment of How Payday Loan Reforms Improve the Health of Minnesota's Most Vulnerable (2016), www.pewtrusts.org /-/media/assets/external-sites/health-impact-project/hip-2o16-payday-lending-report.pdf [https:// perma.cc/S7V6-VBZN].

64 Bd. of Governors of the Fed. Reserve Sys., Report on the Economic Well-Being of U.S. HouseHOLDS IN 2017 - MAY 2018, www.federalreserve.gov/publications/2018-economic-well-being-ofus-households-in-2017-dealing-with-unexpected-expenses.htm.

65 Sarah Holder, Why Cleveland Wants to Bring Back Postal Banking, CityLab (June 4, 2019), www .citylab.com/equity/2019/o6/cleveland-post-office-banking-cash-check-predatory-lending/590557/;

Derek Thompson, Why Don't Americans Save More Money?, The Atlantic (April 19, 2016), www .theatlantic.com/business/archive/2016/o4/why-dont-americans-save-money/478929/.

66 Holder, supra note 65 ; Thompson, supra note 65.

67 Dean Karlan et al., Impact of Savings Groups on the Lives of the Poor, 114 Proc. OF THE NAT'L. ACAD. OF SCI. OF THE U.S. 3079 (2017).

68 Id.

69 See Baradaran, supra note 42.

70 The Times reports a figure of 28 million, but by the end of the year, the Post Office Annual Report states that deposits totaled \$33 million. Postal Savings System Practically Self Sustaining, N.Y. TIMES (May 25, 1913), https://timesmachine.nytimes.com/timesmachine/1913/05/25/100267539.pdf?pdf_re direct=true\&ip=o; U.S. Post Off. Dep’t., Annual Report of the Postmaster General for the Fiscal Year Ended June 30, 19116 (1912); U.S. Post Off. Dep’t, Annual Report of the Postmaster General for the Fiscal Year Ended June 30, 1912 6-7 (1913); US Post Off. Dep't., Annual Report of the Postmaster General for the Fiscal Year Ended June 30, 1913303 (1914). 
in those countries while they were disbanded in the United States and the culture of savings they cultivated abroad. ${ }^{71}$ During World War II, the United States Post Office sold postal savings bonds to schoolchildren and housewives who invested as a patriotic duty. ${ }^{72}$ By the end of World War II, the government had raised about $\$ 8$ billion in additional war funding through war bonds and Treasury bonds sold through the post office..$^{73}$

Today, postal savings accounts have the potential to become a trustworthy receptacle for savings for the financially excluded. Just as our postal banks did successfully for half a century, ${ }^{74}$ their rebirth can lead to increased saving by the broader public. By providing low barrier savings accounts, the post office can again offer a refuge for the countless small savers in the United States who have been shut out of the banking system because their too small savings accounts are no match for high bank fees. Increased access to low-cost savings accounts can greatly benefit a population living without any financial cushion. Even having a few hundred dollars stored away can make a significant difference to a moderate-income family who may face an emergency in their lives. It is difficult to measure how many people are not saving in banks because of financial and cultural barriers of entry, but it is possible that just as in the 190os, hoarded money from across the country would pour into the postal banks from under mattresses, prepaid cards, or funds otherwise wired abroad.

Postal banking may seem radical to many in the United States who are convinced that banking should be a "private market" free from "government intervention," but it is a mundane part of life for the rest of the world. ${ }^{75}$ Postal banking abroad is the norm, not an aberration. ${ }^{76}$ "Posts in 87 countries hold some 2 billion current or savings accounts on behalf of around 1 billion customers." 77 Postal banking is the most successful means of financial inclusion worldwide with several countries, such as India and China, where postal banks are the main driver of financial inclusion in their countries. ${ }^{78}$

71 See Sheldon Garon, Beyond our Means: Why America Spends While the World Saves 374 (2011).

$7^{2}$ Id

73 Nils Clotteau \& Bsrat Measho, Universal Post Union, Global Panorama on Postal Financial INCLUSION 2016 9 (2016), www.upu.int/uploads/tx_sbdownloader/globalPanoramaOnPostalFinancialInclu sionzo16En.pdf [https://perma.cc/EL4S-4EGJ]; US Post Off. Dep’t., Annual Report of the Postmaster General for the Fiscal Year Ending June 30, 194218 (1943); US Post Off. Dep't., Annual Report of the Postmaster General for the Fiscal Year Ending June 30, 1945 13-14 (1946).

74 See Baradaran, supra note 42.

75 Clotteau \& Measho, supra note 73, at 9.

76 Id.

77 Id

78 The World Bank Group, Global Info. \& Comm. Tech. Postal Policy, The Role of Postal Networks in Expanding access to Financial Services: Worldwide Landscape of Postal Financial Services, Asia Region 5, http://documents.worldbank.org/curated/en/ $410191468337292692 / 704230$ ESWoPo850CoBox370041BooooAsia.doc. 
Postal banking has been operational in many Western countries since the 1800 , and currently, fifty-one countries have postal banking as their primary method of financial inclusion - only 6 percent of postal carriers worldwide do not offer banking services. ${ }^{79}$ (It is estimated that postal banking has banked over 1 billion people worldwide. $)^{80}$ There are a variety of models worldwide - some focused on the poor and others that offer postal banking services to the entire population. ${ }^{81}$ In fact, the United States is one of the only developed countries in the world without a postal banking network. ${ }^{82}$ That said, we do not need to look abroad for a justification or even a model for postal banking when we can refer to our own rich history of postal banking. ${ }^{83}$

The transition to postal banking would not require substantial costs or changes to the post office's business. Financial transaction services are straightforward products that do not require a high level of sophistication. The post office can build on its existing network to offer these services. The post office already has the transactional capabilities to deal with cash as well as the back-end security systems in place to transport cash because it sells money orders. A simple ATM machine can be placed inside the post office and tellers can offer debit cards or other transactional services through USPS-contracted servicers or in partnership with a bank. Walmart, for example, came to dominate financial services to the poor, practically overnight, without causing a substantial ripple in its core business. ${ }^{84}$ Walmart attempted to become its own bank in 2005 , but when that route was blocked by regulators, they settled for a partnership with Greendot bank to offer low-cost checking accounts and transactional services. ${ }^{85}$ The company has been able to use its size and existing infrastructure to offer financial products at a fraction of the price while making a healthy profit offering them. Amazon has announced that it will be accepting cash for payment for goods in partnership with brick and mortar stores in order to facilitate transactions for the underbanked. Amazon has claimed that it will not charge fees for these cash transactions. ${ }^{86}$ These large companies are able to

79 Alexandre Berthaud \& Gisela Davico, Universal Postal Union, Global Panorama on Postal Financial InCLusion: Business Models and Key Issues 9-10 (2013), www.uniglobalunion.org/sites/ default/files/pictures/post/globalpanoramafinancial_inclusion_-upu_-en.pdf [https://perma.cc 143 KU-FHB9].

8o Id. at 11 .

81 See id. at 9, 19-20.

82 See id. at $81-82$.

$83 \quad I d$.

84 Zoë Miller, 13 Financial Services Walmart Offers That You Probably Didn't Know About, BanKRATe (April 18, 2019), www.bankrate.com/personal-finance/smart-money/walmart-financial-services /\#slide=1 [https://perma.cc/SLQ9-6HPZ].

85 Ciara Linnane, Green Dot, Wal-Mart Partnership is a Big Milestone: JP Morgan, MarkETWatch (September 25, 2014), www.marketwatch.com/story/green-dot-wal-mart-partnership-is-a-bigmilestone-jp-morgan-2014-09-25 [https://perma.cc/BX 3 Q-49N5].

86 David Z. Morris, You Can Now Pay Cash When Shopping on Amazon. Here's How, Fortune (September 19, 2019), https://fortune.com/2019/og/19/you-can-now-pay-cash-when-shopping-onamazon-heres-how. 
underprice check-cashers and payday lenders due to their ability to cross-subsidize their products. Yet, these large companies do not have an egalitarian mandate. Insofar as offering financial transaction services can lead to greater market dominance through increased sales, they will offer such services, but we should be hesitant to outsource the essential right to participate in commerce to the profit/loss calculations of large corporations.

Estimates show that $\$ 89$ billion is spent each year by the unbanked on financial fees and services, including payday lenders, check cashers, prepaid cards, and other services. ${ }^{87}$ These are significant expenses for families. The average annual income for an unbanked family is $\$ 25,500$, and about 10 percent of that income, or $\$ 2412$, goes to the fees and interest paid to access credit or other financial services - services that those with bank accounts often get for free ${ }^{88}$ If these costs can be reduced through a public option, unbanked and underbanked families would be able to save more money, which would reduce the need for short-term borrowing. Providing these services at much lower costs has a triple advantage of reviving the beleaguered but too-important-to-fail postal service, putting the money back in the pockets of the poor, and providing an alternative to a harmful industry that has proved near impossible to regulate away.

The post office could offer small loans at lower interest rates than the payday lenders. Lending even small loans of less than $\$ 500$ at a reasonable interest rate can help a significant portion of the American public withstand a short-term credit crunch. ${ }^{89}$ Even with more just economic conditions, individuals may occasionally need to borrow small loans to cope with unexpected harms - so must have access to a low-cost loan so that they can survive their illiquidity before it turns into insolvency. In other words, if a person needs $\$ 500$ to pay a bill for food or shelter, will they have to pay an additional $\$ 1000$ in fees to extinguish the loan or something closer to $\$ 50$ in interest? The difference can make the difference between sustainability and bankruptcy. A public option in lending can make a difference to many families struggling to make ends meet.

Consumer protection groups, credit unions, and religious organizations have in the meantime been piloting a number of alternatives to payday lending. In 2010 the National Credit Union Association (NCUA) relaxed its interest rate rules, which limit interest to 15 percent, to permit higher rates on short term, small dollar loans. The credit unions then created Payday Alternative Loans (PALs) provide an economically viable model to credit unions while offering a much cheaper option to consumers seeking short-term loans (with interest of up to 28 percent). Religious

87 See Mehrsa Baradaran, Postal Banking's Public Benefits, 3 Am. Aff. J. 18, 23 (2018).

88 Off. Of the Inspector Gen., U.S. Postal Serv., Providing Non-Bank Financial Services for the UNDERSERVED 2 (2014), www.uspsoig.gov/sites/default/files/document-library-files/2015/rarc-wp-14OO7_o.pdf.

${ }^{89}$ The Post Office White Paper suggests that they can offer loans with a 28 percent APR, a rate sustainable for the Post Office and its customers. Id. at 13. 
organizations even set up their own credit unions: the Friendship-West Baptist Church and St. John Missionary Baptist Church in Dallas established the Faith Cooperative Federal Credit Union as a result of pastoral efforts to protect the churches' congregations from predatory lenders. Likewise, community groups and nonprofits have attempted to offer lower-cost alternatives. Thus far, these initiatives have not been scalable, but have demonstrated that low-interest lending can be a viable business model with limited underwriting. ${ }^{\circ}$

Since the 1990s, governments primarily in the Global South have experimented with conditional cash transfer (CCT) programs to alleviate poverty. These generally involve government payments to individuals or families based on specific behaviors or actions undertaken by the recipients of the funds: children's school attendance, doctor's visits, vaccinations, job training program attendance, and other similar activities. Studies have found that cash aid is more effective than any other form of charitable giving. ${ }^{91}$

\subsection{OBJECTIONS AND DRAWBACKS}

There are some pitfalls to be aware of in designing any public option or utility. Public institutions are just as prone to predation, mismanagement, and fraud as are private organizations. ${ }^{92}$ In order to protect consumers against predatory products or fraud, the USPS would need to be monitored. The USPS has a system of fraud prevention in place through its own regulator and Inspector General. If it decides to lend, the CFPB should be empowered to provide oversight to ensure that consumers are protected. Moreover, the incentive structure of the USPS must be made coherent with its egalitarian mission. Thus far, any profits made by the USPS have been deposited into the US Treasury. ${ }^{93}$ The USPS, unlike most banks and large corporations, is not under pressure by shareholders to maximize profits so it follows that it does not have an incentive to engage in predatory pricing. An example of how a public option can turn toward private profit-making can be found in the example of the GSE Fannie Mae. After Fannie Mae was privatized, its shareholders engaged in fraud and mismanagement. Ultimately, Fannie Mae took on so much risk (for the sake of profit) that it had to be rescued by the federal government. Even without a profit motive, public services can become predatory. An example is the student loan market. Here, the problem is that the Department of Education essentially has a monopoly in the provision of student loans. The Department of Education handles the majority of student loans through private servicers. These servicers have long

90 Susie Cagle, Can a New Kind of Payday Lender Help the Poor?, The Nation (July 9, 2018), www .thenation.com/article/can-new-kind-payday-lender-help-poor/.

${ }^{91}$ Teresa Molina Millán et al., Long-Term Impacts of Conditional Cash Transfers: Review of the Evidence, 34 The World Bank Res. Observer 119, 151 (2019), https://academic.oup.com/wbro/art icle/34/1/119/5492445.

92 The World Bank Group, supra note 78 .

93 Id. 
been accused of fraud and below par service to students seeking information, loan modification, or other services. The Department of Education has been slow to respond to complaints and the private servicers have shielded themselves from all state AG lawsuits by claiming sovereign immunity. ${ }^{94}$ The danger to be avoided here is a lack of sufficient oversight as well as the lack of any market competition. If the post office is the only provider of banking services, it would become a monopoly like the Department of Education and consumers would have no option but to use its products. ${ }^{95}$

The postal banking system would also need a system of strong and accurate underwriting procedures that can adequately separate the insolvent from the merely illiquid and only lend to the latter. Of course, this is easier said than done. There will always be loans that default as long as human beings are responsible for repaying them. Any individual or company, wealthy or poor, can take out too large a loan at too high a cost and be crushed by it. Still, formulas such as credit scores that track an individual's history of previous repayments can eliminate some of the guesswork. But when it comes to distinguishing creditworthy borrowers among the low income, credit scores are often too blunt a tool. Innovative private lenders have already realized this and are working to develop fine-tuned underwriting formulas based on publicly available borrower data to predict loan default with better results than credit scores. ${ }^{96}$ Pioneering peer-to-peer Internet lenders have begun to boast of their success deploying these emerging mathematical models for small lending. ${ }^{97}$ The post office can rely on this developed expertise in designing its own underwriting system. The bottom line is that doing any sort of underwriting, even simply using credit scores, would set the post office apart from the payday lending industry, which currently makes no attempt to distinguish between borrowers. The FDIC reports "the prevailing underwriting criteria of most payday lenders require that consumers need proof only of a documented regular income stream, a personal checking account, and valid personal identification to receive a payday loan." ${ }^{8}$

Distinguishing the merely illiquid from the insolvent is no easy task, but it is at the crux of any successful effort to provide credit to the poor. The credit unions and cooperative thrifts thrived because they succeeded in doing just that. They used the tools available to them at the time: they lent to neighbors and friends and people they already knew through a cooperative structure. Most banks used

94 Id.

95 See Julie Margetta Morgan, Roosevelt Inst., Who Pays? How Industry Insiders Rig the Student LoAn System - And How to Stop Iт (2018), https://rooseveltinstitute.org/wp-content/uploads/2018/ o6/How-Industry-Insiders-Rig-the-Student-Loan-System.pdf [https://perma.cc/FEA6-ZALF].

96 Sarah Todd, An Alternative Lender Whose Credit Reviews Are Academic, Am. BANKER (July 8, 2014), www.americanbanker.com/issues/179_130/an-alternative-lender-whose-credit-reviews-are-academic1068506-1.html [https://perma.cc/9THJ-TC6F].

97 Id.

98 Fed. Deposit Ins. Corp., Payday Lending: An Update on Emerging Issues in Banking 4 (2003), www .fdic.gov/bank/analytical/fyi/or2903fyi.pdf [https://perma.cc/LW4T-QAEP]. 
"character" or "relational lending" to make underwriting decisions. 99 Today, with wide-scale loan standardization, that is less common. Most lenders just plug in numbers to an underwriting formula or algorithm to make decisions. ${ }^{100}$ Even credit unions no longer work the way they used to. Relational lending is difficult today and it would not be a practical way for the post office to lower costs - even though postal employees would probably be best suited for the task. After all, in many rural communities across the country, postal workers have more information about the town's population than any other citizen. However, this is not the case with every community, and it is not clear whether the knowledge acquired by postal workers can be parlayed into accurate loan underwriting without significant training.

And it turns out assessing that risk is surprisingly difficult, but more transparent data collection can be a solution to long-standing problems in this sector. One core barrier to research on the risk profile of payday lenders' clientele is that the payday loan industry uses an entirely different credit scoring system from FICO. It relies on Teletrack, a product of CoreLogic, an analytics and business intelligence company that had its roots in real estate. Teletrack captures data from categories of businesses that do not report to the major credit bureaus, such as "including payday loans, rentto-own business, furniture stores, auto finance, subprime credit card issuers, and debt buyers" (The Balance). So, research reports that find, for example, "little to no effect of payday loans on credit scores, new delinquencies, or the likelihood of overdrawing credit lines" are probably flawed, because credit scores do not include data from these fringe banking businesses. ${ }^{101}$

This also means that in order to design an alternative to payday lending, questions about which data and metrics to use to score risk need fresh solutions. Some online lending services claim to use alternative sources of data to predict default, including those collected by TeleTrack. The three major credit-rating agencies are beginning to leverage alternative data, as well (with TransUnion having purchased the alternative data company FactorTrust, Experian touting its use of rental, utility, and other payment data, and Equifax partnering with data company Urjanet to leverage socalled consumer-permissioned data, or data a consumer shares with a business at the time of a transaction). Banks, credit unions, consumer protection groups, and financial justice advocates have been raising concerns about the potential for algorithmic risk scoring based on alternative data to result in a kind of digital redlining, replicating the problems of discrimination in lending that the original credit-rating agencies were meant to mitigate.

99

$100 \quad I d$

101 "Payday Loans and Consumer Financial Health." Bhutta, Neil. Journal of Banking \& Finance, 2014. 
The Filene Research Institute's Reaching Minority Households Incubator has been testing a payday lending alternative driven by alternative credit scoring using LexisNexis Risk View. Risk View uses, among other things:

- Age and Predicted Income-related Attributes

- New Property Automated Valuation Model (AVM) attributes to reveal prospects' property values

- Education Attributes

- Characteristics of Input and Previous Address Attributes

- Most Recent Property Sale Attributes

- Transient Person Attributes

- Sub-prime Credit Service Solicitations Attributes

- Phone and Higher Risk Address Attributes ${ }^{102}$

The preliminary results of Filene's experiment are promising. It reports: "Kinecta Federal Credit Union and Nix Neighborhood Lending's program consolidates up to $\$ 2,500$ of high-cost debt into an affordable installment loan. To date the program has issued over 11,700 loans with net charge-off rates of less than 6\%."103

At the same time, the potential for algorithmic discrimination remains. Scholars and activists have repeatedly pointed out the ubiquity of race and gender discrimination in AI even when algorithms avoid using obvious race and gender categories (Race after AI, Algorithms of Oppression) Politico raised concerns, for example, about Risk View associating relatives and roommates of people who abuse opioids with opioid use (Politico 2019) - which may be a correct association, but problematic when used to assess health insurance premiums. Regardless of this specific example, there is growing awareness in the computer science and engineering community as well as in consumer protection that algorithmic decision-making will need to proceed in a fair, accountable, transparent, and ethical manner.

The post office or any public banking option must learn to adapt existing modern technology to offer fair, useful, and self-sustaining products to those neglected by mainstream banks.

\subsection{THE CASE FOR POSTAL BANKING}

There are several reasons to believe that the post office is uniquely capable of lending responsibly while reducing the costs of small loans. First, and most importantly, the post office is not primarily motivated by profitmaking, but rather is committed to a public service mission. Therefore, it can charge borrowers the actual

102 LexisNexis RiskView Solutions is a Comprehensive Suite of Proven Credit Risk Management Data Analysis Tools and Non-tradeline Data, LexISNExIs, https://risk.lexisnexis.com/products/riskview (last visited May 5, 2020).

103 Payday Payoff Installment Loans, FiLENE Res. InsT., https://filene.org/do-something/programs/pay day-payoffı (last visited May 5, 2020). 
cost of the loan. This was the necessary premise behind every successful movement to foster financial inclusion. The post office is not profit motivated because it is an independent agency connected to the federal government, meaning that all excess profits are forfeited to the Treasury. ${ }^{104}$ The post office has no shareholders demanding a return on investment so it is unlikely that the organization will be motivated to take advantage of its customers for private gain. ${ }^{105}$ All gains will be public, as will losses. A board of directors, public representatives chosen by a democratically elected president, should be tasked to oversee its activities with an Inspector General's office doing periodic audits as well as an independent regulatory agency that has rate-setting power. ${ }^{106}$

Second, the post office can naturally reduce the high costs of lending to the poor through "economies of scale" and "economies of scope." 107 It can use its already existing and large network of branches to sell new products without much additional startup, overhead, or marketing costs. Compared to payday lenders, the post office can reduce costs immediately by using its existing branches and staff thus saving money otherwise spent on advertising, personnel, and locations. This ability to offer more at a lower cost is the reason large banks now dominate the market. Likewise, the size and reach of the post office can lead to lower costs of credit. "Economies of scale," or control of a large market of a single product, could bring down the costs for financial services and even loans if the post office has many customers. "Economies of scope," costs saved when an institution can sell a variety of products, could mean, for example, lower costs on loans because the post office is attracting more deposits, cashing more checks, or wiring more funds. ${ }^{108}$

Finally, because the post office never left communities deserted by banks and other businesses, it is available in all the regions forsaken by banks and has also developed an ongoing relationship of trust within these communities. ${ }^{109}$ Many unbanked individuals already buy their money orders at their local post office. ${ }^{110}$ This means that the post office has access to a customer base that is not comfortable in banks. ${ }^{111}$ Surveys of the unbanked show that minority groups are significantly

104 See Task Force on the U.S. Postal Sys., Dep’t. of the Treasury, United States Postal Service: A Sustainable Path Forward 5, 33 (2018), https://home.treasury.gov/system/files/136/ USPS_A_Sustainable_Path_Forward_report_12-04-2018.pdf [https://perma.cc/Q6AU-L4J8].

105 Id.

106 Off. of the Inspector Gen., U.S. Postal Serv., Governance of the U.S. Postal Service 1, 18 (2016), www.uspsoig.gov/sites/default/files/document-library-files/2016/RARC-WP-17-ooz.pdf.

107 Cathy M. Rogerson et al., Economies of Scale and Scope and Competition in Postal Services, in 12 Topics in Regulatory Economics and Policy Series: Regulation and the Nature of Postal and Delivery Services (1993).

108 Steven Nickolas, How do Economies of Scope and Economies of Scale Differ?, InVESTOPEDia (May 6, 2019), www.investopedia.com/ask/answers/042215/what-difference-between-economies-scope-andeconomies-scale.asp [https://perma.cc/U9 $\left.\mathrm{H}_{5}-\mathrm{QDMC}\right]$.

109 See Baradaran, supra note 87 , at 27.

110 Id.

111 Id. 
more likely to be unbanked than other groups. ${ }^{112}$ But the cultural and class barriers that keep many people away from the mainstream banks do not exist at the local post office. Americans rank the USPS highest among all federal agencies with more than 70 percent of those polled saying it does an excellent or good job. ${ }^{113}$ With millennials, the rate is even higher at 81 percent. ${ }^{114}$ About 70 percent of Americans trust the post office compared to 18 percent who trust payday lenders and 26 percent who trust banks. ${ }^{115}$

In both inner-city and rural communities, the post office can be crowded and bustling places where the neighborhood gathers to do its business, helped by clerks who are members of that same community. Even people who never go to the post office branch may be familiar with the mail carrier who visits their home daily. And following history's cue, the postal network can offer information in more languages than do banks and appeal to the large population of immigrants or even the undocumented who have money to save, but no access to banks. Many of these workers currently send their money abroad ${ }^{116}$ - money that can be induced to stay within American borders. As it was in the 1900s, this can be a surprising source of revenue for the postal banks.

Trust, especially in banking, is more than just a nice feeling. It is a way to lower costs and reduce barriers of entry. This was the point of government deposit insurance. Banks cannot survive if their customers do not trust them to hold and lend their money. It is hard to predict whether the public will warm to postal banking, but in light of historical and international experience, and the significant modern distrust of fringe banks, the public may view the post office as a safer and more trustworthy place to store funds.

And this trust is not undeserved. The post office has a history of service to the American people, unrivaled by any other institution or any other government entity. In a way, the post office serves as a perfect foil for the banking industry. The latter receives hefty federal government support and rejects any public-serving functions and the former is currently receiving limited federal government support and yet sees public service as its primary mission. Even today, the stated mission of the US

112 Fed. Deposit Ins. Corp., 2017 FDIC National Survey of Unbanked and Underbanked Households 10 (2018), www.fdic.gov/householdsurvey/2017/2017report.pdf.

113 Steve Ander \& Art Swift, Americans Rate Postal Service Highest of 13 Major Agencies, Gallup (November 21, 2014), https://news.gallup.com/poll/179519/americans-rate-postal-service-highestmajor-agencies.aspx [https://perma.cc/J6CM-YR 5 C].

114 Id.

115 Dennis Jacobe, Americans' Confidence in Banks Up for First Time in Years, Gallup (June 13, 2013), https://news.gallup.com/poll/163073/americans-confidence-banks-first-time-years.aspx [https://perma .cc/WTZ4-MQPQ]; Peter Moore, Poll Results: Post Office Bank, YouGov (February 10, 2014), https:// today.yougov.com/topics/finance/chapters-reports/2014/oz/10/poll-results-post-office-bank [https:// perma.cc/MPZg-EAND].

116 William Lacy Swing, How Migrants Who Send Money Home Have Become a Global Economic Force, WORLD ECON. F. (June 14, 2018), www.weforum.org/agenda/2018/o6/migrants-remittance-globaleconomic-force/ [https://perma.cc/B9RV-A2 $\mathrm{CY}$ ]. 
post office is: "to provide postal services to bind the Nation together through the personal, educational, literary, and business correspondence of the people. It shall provide prompt, reliable, and efficient services to patrons in all areas and shall render postal services to all communities."117 This makes the post office an ideal means of providing a public option in banking.

Short-term credit is not a solution to inequality. The reason that most people need high-cost credit products is unstable work, inequality, and rising costs in health care and education - and the best solution is not credit, but addressing these structural problems. Full-scale reform of the economy is necessary to right the ship - employees must have a living wage, families must have affordable shelter, and health-care costs must not be so onerous. With these reforms in place, the need for payday loans will naturally be diminished. The industry, after all, has risen alongside trends in inequality. ${ }^{118}$ Yet, credit can be a lifeline for many families and individuals who face unexpected circumstances.

A public option can take many forms and can offer an alternative for all banking services or it can be limited to small loans and bank accounts for the underbanked. Participation in commerce is essential for full civic engagement and today, many Americans are excluded from commerce or forced to pay fees for simple loans and transactions. A public option has the potential to resolve these inequalities. For a variety of historic and practical reasons, the US Postal System would be the best means of offering a public option to all communities.

117 The United States Postal Service is an independent establishment of the Executive Branch of the Government of the United States and operates in a business-like way. Its mission statement can be found in Section 101(a) of Title 39 of the U.S. Code, also known as the Postal Reorganization Act. Pub. L. 91-375, 84 Stat. 719 (1970) (codified as 39 U.S.C. $\int 101(a)$ ).

118 Payday lending began to increase in the late 1980 and has risen since then, as has inequality. See John P. Caskey, Fringe Banking: Check-Cashing Outlets, Pawnshops, and the Poor 6 (1994); Gregory Elliehausen \& Edward C. Lawrence, A Comparative Analysis of Payday Loan Customers, 26 Contemp. Econ. Pol'y 299 (2008). 
